\title{
ВСПЫШКА - ФЕЙЕРВЕРК - СВЕЧЕНИЕ
}

(По поводу казанского сборника "Распространение знаний о международном гуманитарном праве, 1997 г.”)

Все мы - одни чаще, другие реже - видели на экранах телевизоров взрыв атомной бомбы: вспышка, от которой как бы отпадают небольшие фейерверки, а затем долгое свечение огромного "гриба". Даже с экрана устрашаюшее зрелище.

То, что произошло в Казани в мае 1997 года, по своему значению для гуманитарного права в России можно сравнить со взрывом атомной бомбы. Правда, она никого не опалила, не покалечила. Но она озарила сознание, она заставила думать по-новому многих официальных лиц.

После этого события в новом стандарте профессионального образования в области юриспруденции для высшей школы появились три слова: "международное гуманитарное право". После него все чаще в средней школе проводятся уроки по курсу международного гуманитарного права, а с сентября 1998 года эта дисциплина вошла в программу для многих старшеклассников. Не говоря уже о том, что международное гуманитарное право преподается во многих вузах наших силовых структур. И способствовал тому приказ министра обороны, изданный еще во времена Советского Союза.

И все-таки нынешнее внимание к международному гуманитарному праву в России не сравнимо ни с чем: семинары, конференции, конгрессы по этому праву следуют один за другим.

А ларчик-то открывается просто. Есть в Москве представительство Международного Комитета Красного Креста (MKKK). А в этом представительстве до последних месяцев работал моторный человек Стефан Хенкинс, который отвечал за распространение международного гуманитарного права на всей территории бывшего СССР. Вот и летал он на самолетах, ездил на поездах и машинах, встречался с государственными деятелями и парламентариями, ректорами и студентами, профессорами и аспирантами, убеждал, доказывал, сам, где попросят, читал лекции этот человек. Это от него идет свечение по всей нашей бывшей огромной стране, а сейчас - по всему СНГ. Он - как фонарщик на главной улице: чуть где притух фонарик, надо фитилек выровнять, масла подлить и поджечь его вновь.

Вот и на книжице, о которой идет речь, на первой странице вместо слов "Международный Комитет Красного Креста" надо было бы поставить: "Стефан Хенкинс". Даже несмотря на то, что составители вынесли его вступительную речь в самое начало издания. 
Значение Казанской конференции огромно. Здесь впервые во все трубы затрубили юристы-международники о гуманитарном праве. Здесь впервые подняли свой голос военные, хотя и приехали они сюда, на эту миролюбивую встречу, в штатском.

Можно даже сказать больше. Казанская конференция поставила хорошую точку в споре двух открыто враждебных группировок по вопросу о том, что такое международное гуманитарное право. Посмотрите учебники, послушайте ученых. Ведь кто в лес, кто по дрова. Одни утверждают: это часть раздела прав человека, а другие -права человека во время вооруженного конфликта да еще и сам вооруженный конфликт впридачу: правила его ведения, ограничения, существующие в международном праве, на ведение конфликта.

Я - за вторую точку зрения. В любых единоборствах есть правила. И в восточных, и в западных, и в российских. И везде одноединое: лежачего не бьют. Так какой же перст свыше указал издеваться над военнопленными?

Или заложничество! Зло, что расцвело именно в наши дни. Хотя знали его исстари. Еще в XVI веке всего шесть лет была королевой Шотландии Мария Стюарт. В 25 лет попала в заложницы к английской Елизавете, и та в течение 20 лет измывалась над волевой красавицей, пытаясь сломить ее дух. Не вышло. И тогда неправый суд, топор палача и... скулящий песик у отрубленной головы.

Ныне заложничество стало бичом времени. В заложники берут отрядами и группами, журналистов и особенно иностранцев. До королев и президентов добраться трудно, а вот полномочного представителя России можно сделать заложником за милую душу. И пусть гадают те, кому положено, жив ли, кем схвачен, где спрятан, почему, кому это выгодно... Вопросы, вопросы, бесконечные вопросы. А четких ответов-то нет. Ни у абреков чеченских, ни у царей московских.

Потому-то и сползают отношения Москвы и .Грозного лишь к поиску захоронений погибших воинов, К опознанию останков, извлеченных из-под земли.

Было бы все это, если бы солдат наш и солдат чеченский знали элементарные нормы международного гуманитарного права? Если бы знали, что раненый - это уже не воин и его надо отправить в лазарет, что с пленным надо обращаться уважительно, а по мирному населению и по мирным объектам стрелять нельзя? Не знали они этого ничего. Не только солдаты, но даже многие офицеры, не говоря уже о полевых командирах.

Вот и получила та война эпитеты: жестокая, кровавая, бессмысленная.

Спасает нас MKKK. Спасают нас Хенкинс и его многочисленные помощники из числа чиновников правительственных структур, профессуры, даже аспирантов. 
За минувший 1997 год лучшие юристы-международники России получили почетные премии имени Гуго Гроция. Многие из лауреатов этой премии были либо организаторами, либо активными участниками Казанской конференции. С одним из основных докладов там выступил первый среди равных, заведующий кафедрой международного права МГИМО(У) МИД РФ профессор Ю.М. Колосов. Блестящую речь произнес академик И.П. Блищенко (еще один Гроциевский лауреат). Но всех поразила аспирантка (тоже гроциевский лауреат) Казанского университета А.Ю. Галяметдинова. Она не только дала подробный отчет о конференции в "Московский журнал международного права", но и сумела написать для сборника об этой же конференции большую и серьезную статью с выводами, которых еще не знала наука международного права. Она впервые и смело разрабатывает принципы экологической безопасности, но вместе с тем правильно замечает, что идея о защите окружающей среды во время вооруженного конфликта, если она вообще осознается, занимает одно из последних мест в представлении военных. И вывод: начинать надо с начальников. Пусть они, планируя военные операции, думают, что тем самым могут натворить на земле. Вот такой женский, любовный взгляд на родную планету. Правильный взгляд!

Казанский сборник интересен и тем, что его составители не пошли по шаблону: взять стенограмму и прописать ее до тех пор, пока она не уляжется в заданный объем. Нет. Листая его, я почему-то слышал те приятные мелодии Бородина, Вивальди и Гайдна, с которых началась конференция. Это было неожиданно и красиво. Мир прекрасен, говорила музыка, думайте об этом, когда будете рассуждать о войне.

Таким же неожиданным по композиции оказался и сам сборник. В нем не было выступлений тех, кто высказывался спонтанно, без бумажки, как тот “единственный неграмотный, не умевший читать на XX съезде КПСС - президент Академии наук СССР, академик Александров". (Выступавшие не предоставили тексты своих речей.) Зато буйно была представлена молодежь, которая рассмотрела практически почти весь спектр проблем.

И еше понравилось то, что выводы и рекомендации конференции вынесены почти в самое начало. Вот, мол, уставшие от чтения обилия бумаг чиновники: читайте сразу, что надо делать, не надо листать эту книжицу до конца. Это вам рекомендуют ученые, собравшиеся в Казани со всей России.

В. Пархитько

Речензия поступила в редакцию в июне 19982. 